\title{
PENINGKATAN KETERAMPILAN MENULIS PUISI MELALUI KARTU KATA (KAKA) SEBAGAI MEDIA PEMBELAJARAN
}

\author{
KAIYAN \\ Guru SD Negeri Jemirahan Kecamatan Jabon, Sidoarjo, Jawa Timur \\ email : kaiyanjemirahan93@gmail.com
}

\begin{abstract}
ABSTRAK
Pada pembelajaran bahasa Indoensaia pada kompetensi dasar menulis puisi bebas dengan pilihan kata yang tepat sering menjadi masalah, khusunya pada siswa kelas V-A di SDN Jemirahan kecamatan Jabon. Diketahui bahwa masalah utama dari pembelajaran bahasa Indonesia pada kompetensi dasar menulis puisi bebas di kelas V-A di SDN Jemirahan ini adalah sedikitnya penguasaan kosa kata yang dimiliki siswa dalam pembuatan puisi dan benturan antara pengalaman belajar yang dimiliki siswa di kelas sebelumnya dengan konsep yang dipelajari atau yang diajarkan guru. Penelitian ini merupakan Penelitian Tindakan Kelas dengan dua siklus dengan mengadopsi model kemmis and taggart. Berdasarkan permasalahan tersebut peneliti mencoba menghadirkan KAKA sebagai media pembelajaran untuk lebih menemukan dan menerapkan perolehan konsep menulis puisi bebas, sehingga peneliti mengambil permasalahan Bagaimanakah peningkatan keterampilan menulis puisi melalui KAKA sebagai media pembelajaran siswa klelas V-A SD Negeri Jemirahan Jabon Sidoarjo? Berdasarkan data pada kondisi awal diperoleh 12,5\% memperoleh nilai minimal ketuntasan belajar $\geq 70$, dengan observasi perbaikan diperoleh peningkatan prestasi belajar siswa pada siklus I terdapat 62,5\% mencapai nilai Standar Ketuntasan Belajar yaitu $\geq 70$, pada siklus II terdapat $87,5 \%$ mencapai nilai ketuntasan yaitu $\geq 70$. Dari hasil perbaikan pembelajaran yang dilaksanakan oleh peneliti maka dapat ditarik kesimpulan bahwa KAKA sebagai media pembelajaran dapat meningkatkan keterampilan menulis puisi pada siswa kelas V-A SD Negeri Jemirahan Jabon Sidoarjo.
\end{abstract}

Kata Kunci : Prestasi Belajar, KAKA, Puisi Bebas

\section{PENDAHULUAN}

Bahasa memiliki peranan sentral dalam perkembangan intelektual, sosial, dan emosional peserta didik dan merupakan penunjang keberhasilan dalam mempelajari semua bidang studi. Pembelajaran bahasa diharapkan membantu peserta didik mengenal dirinya, budayanya, dan budaya orang lain, mengembangkan gagasan dan perasaan, berpartisipasi dalam masyarakat yang menggunakan bahasa tersebut, dan menemukan serta menggunakan kemampuan analitik dan imaginatif yang ada dalam dirinya tertuang dalam Standar Kompetensi Mata Pelajaran Bahasa Indonesia SD. (Depdiknas, 2006).

Berbahasa pada dasarnya adalah proses interaktif komunikatif yang menekankan pada keterampilan berbahasa. Kemampuan memahami keterampilan berbahasa tersebut sangat menentukan keberhasilan dalam proses komunikasi. Keterampilan berbahasa tersebut mencakup keterampilan menyimak, berbicara, membaca, dan menulis. Keempat keterampilan itu tidak dapat berdiri sendiri. Penggunaan bahasa sebagai proses komunikasi dari keempat keterampilan tersebut tidak dapat dipisahkan satu sama lain. Hal ini menunjukkan bahwa bahasa merupakan keterpaduan dari beberapa keterampilan sebagai alat komunikasi.

Sebagai salah satu aspek keterampilan berbahasa, kemampuan yang diharapkan dalam pembelajaran menulis, khususnya tentang menulis sastra adalah siswa mampu 
mengungkapkan pikiran, perasaan, informasi dan fakta secara tertulis dalam bentuk ringkasan, laporan, dan puisi bebas seperti dalam Standar Kompetensi Mata Pelajaran Bahasa Indonesia SD. (Depdiknas, 2006: 66).

Menulis Puisi merupakan kegiatan imajinatif yang dialami penulis berdasarkan pengalaman-pengalamannya, baik dari diri sendiri maupun dari orang lain. Pengalamanpengalaman itu berupa fakta yang dirasakan, dilihat, didengar, atau pengalaman batinnya yang di bawah sadar. Dalam proses pencapaian tujuan pembelajaran atau kompetensi dasar, khususnya pembelajaran menulis puisi sudah diupayakan dengan beberapa cara, misalnya menulis puisi berdasarkan pengamatan, menuliskan perasaan yang sedang dialami dalam bentuk puisi, mengungkapkan gagasan atau pikiran dalam bentuk puisi dan pengalaman melalui berbagai indra dirinya dalam bentuk puisi

Kenyataan selama ini menunjukkan bahwa siswa kelas V-A SD Negeri Jemirahan Kecamatan Jabon Kabupaten Sidoarjo, keterampilan menulis puisinya masih rendah. Selain itu puisi yang dihasilkan para siswa masih jauh dari harapan. Mereka masih mengalami kesulitan untuk menulis puisi karena kosa kata yang dimiliki sangat minim dan kurang menunjang untuk menciptakan sebuah karya puisi. Hal ini dapat dilihat dari hasil karya puisi siswa yang belum memenuhi kaidah penulisan puisi. Berdasarkan hasil awal didapatkan data bahwa dari 24 siswa, hampir seluruh siswa mendapatkan nilai rendah/di bawah nilai standar yaitu 65. Kondisi tersebut mungkin juga dipengaruhi oleh faktor kondisi siswa, sumber belajar, media pembelajaran, dan metode pembelajaran.

Untuk mengatasi permasalahan tersebut, perlu direncanakan alternatif atau solusinya, yaitu dengan penggunaan media Kartu Kata (KAKA). Penggunaan KAKA sebagai media pembelajaran dapat merangsang anak untuk berperan aktif, membangkitkan motivasi belajar dan membantu mempermudah siswa dalam menulis puisi, sehingga keterampilan menulis puisi siswa dapat meningkat. Karena itu dalam penelitian tindakan kelas ini peneliti akan menggunakan media KAKA sebagai upaya meningkatkan keterampilan menulis puisi siswa kelas V-A, maka tepatlah kiranya apabila peneliti merumuskan judul "Peningkatan Keterampilan menulis Puisi Melalui KAKA Sebagai Media Pembelajaran Siswa Kelas V-A SD Negeri Jemirahan Kecamatan Jabon Kabupaten Sidoarjo Tahun Pelajaran 2010/2011”.

Agar tidak terjadi salah persepsi terhadap judul penelitian ini,maka perlu didefinisikan sebagai berikut: (1) KAKA (kartu kata) adalah beberapa potongan kertas (kartu) yang bertuliskan kata, (2) Media KAKA adalah media yang terbuat dari beberapa kartu yang tertuliskan sebuah kata yang nantinya sebagai sarana pengungkapan ekspresi menulis puisi, dan (3) Prestasi belajar yang diharapakan adalah siswa dapat membuat puisi yang baik.

\section{METODE PENELITIAN}

Penelitian ini merupakan Penelitian Tindakan Kelas dengan dua siklus. Tempat penelitian di SD Negeri Jemirahan Kecamatan Jabon Kabupaten Sidoarjo. Penelitian dilakukan pada bulan April sampai dengan Juni 2019. Mata pelajaran yang menjadi sasaran penelitian ini adalah mata pelajaran matematika kelas $\mathrm{V}$ khususnya untuk kompetensi dasar mengukur sudut. Sasaran dalam penelitian ini adalah siswa kelas V A SD Negeri Jemirahan Kecamatan Jabon Kabupaten Sidoarjo Tahun Pelajaran 2018/2019 yang mempunyai siswa sebanyak 24 siswa.

Penelitian ini menggunakan Penelitian Tindakan Kelas (classroom action research), Penelitian tindakan kelas adalah suatu bentuk kajian yang bersifat reflektif oleh pelaku tindakan yang dilakukan untuk meningkatkan kemantapan rasional dari tindakan mereka 
dalam melaksanakan tugas, memperdalam pemahaman terhadap tindakan-tindakan yang dilakukan itu,serta memperbaiki dimana kondisi praktik pembelajaran tersebut dilakukan.

Secara umum penelitian tindakan kelas menurut Mulyasa (2008:155) bertujuan untuk (1) memperbaiki dan meningkatkan kondisi serta kualitas pembelajaran di kelas, (2) meningkatkan layanan profesional dalam konteks pembelajaran, (3) memberikan kesempatan kepada guru untuk melakukan tindakan dalam pembelajaran yang direncanakan di kelas, dan (4) memberikan kesempatan kepada guru untuk melakukan pengkajian terhadap kegiatan pembelajaran yang dilakukan.

Pelaksanaan Perbaikan Pembelajaran tiap Siklus, terdiri (1) Perencanaan Pembelajaran, (2) Pelaksanaan Pembelajaran, (3) Pengumpulan Data/Observasi, dan (4) Refleksi. Dalam penelitian ini instrumen yang digunakan adalah bentuk tes dan non tes. Bentuk tes berupa tugas menulis puisi, tugas ini dikerjakan dengan bantuan media kartu kata yang harus dikembangkan menjadi beberapa kata yang mengandung ide/gagasaan yang lengkap, sedangkan bentuk non tes berupa wawancara untuk mengetahui respon siswa terhadap penggunaan kartu kata sebagai media pembelajaran. Data-data yang diperlukan dalam penelitian ini diperoleh melalui hasil kerja siswa dalam menulis puisi pada tiap siklus.

Untuk menganalisis tingkat keberhasilan atau presentase keberhasilan siswa setelah proses belajar mengajar setiap siklus dilakukan dengan cara memberikan nilai pada hasil kerja siswa dalam membuat nilai pada setiap akhir siklus.

Analisis ini dihitung dengan menggunakan statistik sederhana yaitu :

1. Menghitung persentase Prestasi Belajar siswa (daya serap) persiklus dengan menggunakan rumus :

$$
\text { Persentase }(\%)=\frac{\text { Jumlah jawab benar }}{\text { Nilai maksimum }} \times 100 \%
$$

2. Menghitung persentase ketuntasan kelas dengan menggunakan rumus :

$$
\text { Ketuntasan Kelas }=\frac{\text { jumlah. siswa yang tuntas belajar }}{\text { jumlah siswa }} \times 100 \%
$$

Siswa secara berkelompok atau satu kelas dianggap tuntas belajar bila ketuntasan kelas mencapai $\geq 80 \%$ dari jumlah siswa yang mencapai daya serap $\geq 70 \%$ (Purwanto Ngalim: 2008)

\section{HASIL PENELITIAN DAN PEMBAHASAN}

KAKA dalam penelitian ini adalah kartu yang berisi kata atau kelompok kata/frase dengan urutan tertentu sehingga membantu siswa dalam mengembangkan gagasan hingga tercipta sebuah puisi. Kata-kata atau kelompok kata yang dipilih didasarkan pada topik-topik yang diminati siswa dan disesuaikan dengan lingkungan siswa. KAKA yang digunakan dalam siklus I dan II dalam penelitian ini terdiri dari 20-25 kartu, dan pada tes akhir terdiri dari 16-20 kartu kata. Pada siklus I dan II jumlah kartu kata yang digunakan lebih banyak karena pada kedua siklus ini siswa menyelesaikan lembar kerja dalam bentuk kelompok dengan harapan akan terjadi curah pendapat dari setiap anggota sehingga menghasilkan sebuah puisi yang mengandung ide/gagasan yang lengkap. Pada tes akhir siswa menyelesaikan soal secara individu. Dengan memanfaatkan segenap kemampuan yang ada siswa berupaya untuk menciptakan puisi yang baik. Contoh penulisan puisi dengan menggunakan kata atau kelompok kata adalah sebagai berikut: (1) Perhatikan kata atau kelompok kata yang ada sesuai dengan urutan nomer! (2) Kembangkanlah kata atau 
kelompok kata yang ada menjadi baris-baris puisi! (3) Susunlah baris-baris puisi yang ada menjadi bait-bait yang mengandung ide/gagasan yang lengkap sehingga menjadi sebuah puisi! (4) Tulislah judul yang tepat sesuai dengan isi puisi!
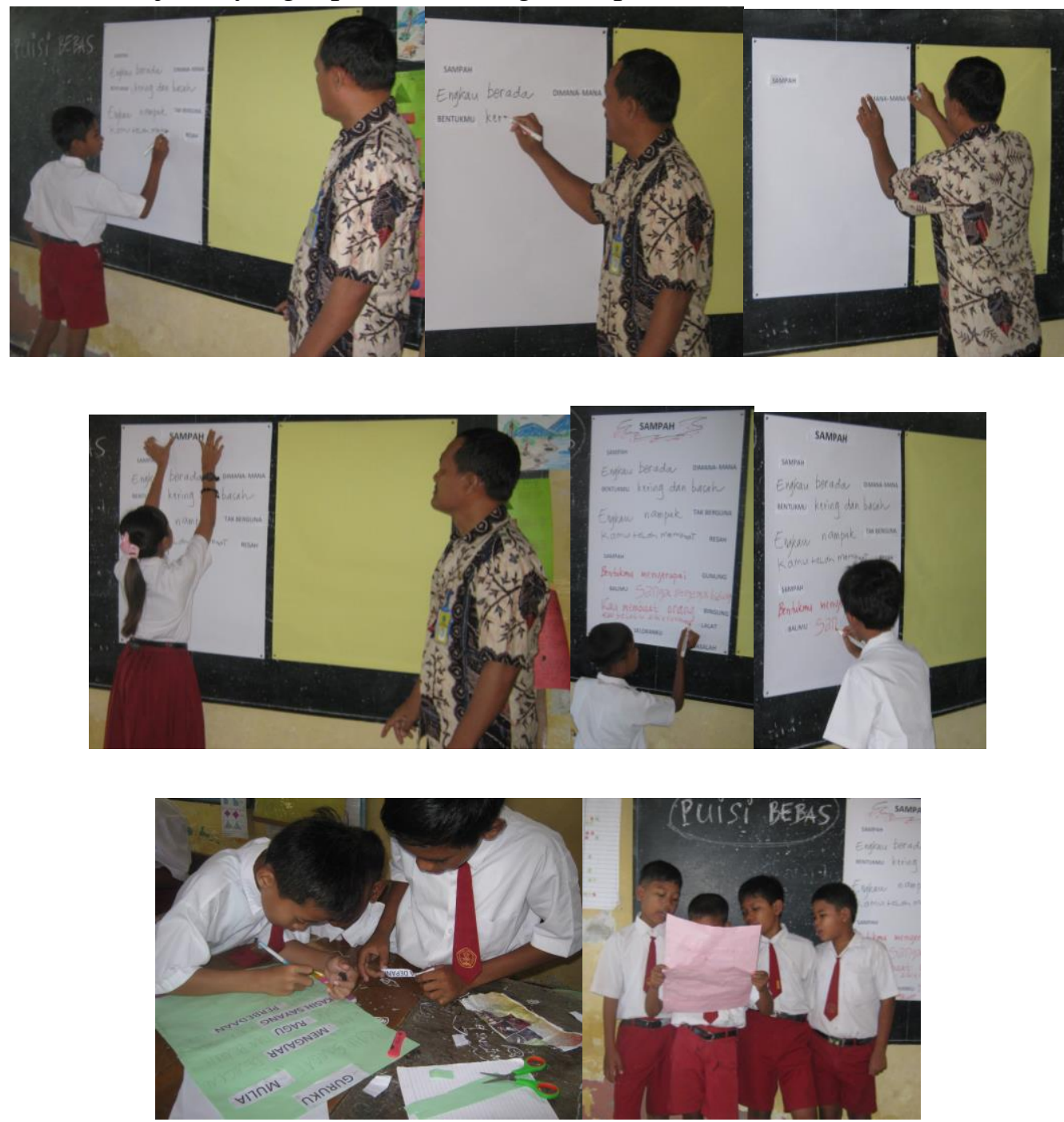

Gambar 1. Praktek penerapan KAKA pada siswa sekolah dasar pada siklus 1

Media merupakan suatu alat untuk menyampaikan pesan (message) atau informasi dan sesuatu sumber ( resource) kepada penerima (receiver). Dilihat dari jenisnya, kartu kata termasuk jenis media cetak. Sebagai media pembelajaran kartu kata dalam penelitian ini adalah kata atau kelompok kata yang merupakan kata kunci untuk mengembangkan ide/gagasan. KAKA yang terdiri atas kata atau kelompok kata yang berfungsi sebagai kata kunci sangat membantu siswa dalam mengembangkan ide/gagasan yang lengkap sehingga hasil karya puisi siswa lebih baik dan meningkat sesuai dengan kreativitas masing-masing. Dengan demikian dapat dikatakan bahwa keterampilan siswa dalam hal menulis puisi akan lebih baik dan meningkat karena adanya media pembelajaran yang berupa kartu kata yang sangat membantu siswa dalam mencipta sebuah puisi.

Setelah proses pembelajaran pada siklus I selesai, diakhir siklus diadakan penilaian pembelajaran dengan hasil sebagai berikut : 
Tabel 1 : Nilai Prestasi Siswa pada Siklus I

\begin{tabular}{|c|l|c|c|c|c|c|c|c|}
\hline No & \multicolumn{1}{|c|}{ Nama Siswa } & Diksi & Citraan & $\begin{array}{c}\text { Kata } \\
\text { Konkre }\end{array}$ & $\begin{array}{c}\text { Bahasa } \\
\text { Kiasan }\end{array}$ & Rima & $\begin{array}{c}\text { Jumlah } \\
\text { Skor }\end{array}$ & $\begin{array}{c}\text { Rata } \\
\text { Nilai }\end{array}$ \\
\hline 1 & Rudi Andriansyah & 70 & 65 & 70 & 70 & 75 & 350 & 70 \\
\hline 2 & Ela Firanti & 70 & 65 & 64 & 65 & 70 & 334 & 67 \\
\hline 3 & Indah Wati & 65 & 65 & 64 & 61 & 65 & 320 & 64 \\
\hline 4 & Moch. Muklis Efendi & 70 & 70 & 70 & 65 & 70 & 345 & 69 \\
\hline 5 & Putri Sukmawati & 78 & 68 & 69 & 68 & 75 & 358 & 72 \\
\hline 6 & Adi Irawan & 75 & 70 & 73 & 70 & 75 & 363 & 73 \\
\hline 7 & Arina Hidayati & 72 & 70 & 69 & 65 & 73 & 349 & 70 \\
\hline 8 & Achmad Zakariya & 80 & 65 & 70 & 75 & 75 & 365 & 73 \\
\hline 9 & Aldina Wahyu W. & 72 & 70 & 69 & 65 & 73 & 349 & 70 \\
\hline 10 & Achmad Alif Asy'ari & 65 & 65 & 72 & 68 & 69 & 339 & 68 \\
\hline 11 & Ari Rusiawan & 69 & 70 & 69 & 65 & 67 & 340 & 68 \\
\hline 12 & Ade Rukmana & 78 & 70 & 75 & 76 & 78 & 377 & 75 \\
\hline 13 & Achmad Saifuddin & 75 & 74 & 76 & 75 & 78 & 378 & 76 \\
\hline 14 & Choirun Nur Asfiah & 69 & 65 & 66 & 63 & 70 & 333 & 67 \\
\hline 15 & Dwi Adinda Sari & 78 & 77 & 75 & 76 & 78 & 384 & 77 \\
\hline 16 & Dinda Nur Sabilah & 75 & 70 & 73 & 70 & 75 & 363 & 73 \\
\hline 17 & Detta Eka Amalia & 75 & 74 & 76 & 75 & 78 & 378 & 76 \\
\hline 18 & Eka Cahyati & 69 & 60 & 66 & 70 & 70 & 335 & 67 \\
\hline 19 & Firdausi Nuzula & 75 & 74 & 76 & 75 & 78 & 378 & 76 \\
\hline 20 & Kamaluddin Zuhri & 75 & 74 & 76 & 75 & 78 & 378 & 76 \\
\hline 21 & M. Zaim Al Faiq & 75 & 74 & 76 & 75 & 78 & 378 & 76 \\
\hline 22 & Muh. Naufal D & 70 & 63 & 64 & 61 & 60 & 318 & 64 \\
\hline 23 & Moh. Efendi Firman & 60 & 60 & 60 & 61 & 60 & 301 & 60 \\
\hline 24 & Moh. Rukhan Hafidz & 69 & 65 & 75 & 75 & 75 & 359 & 72 \\
\hline & Jumlah & 1729 & 1643 & 1693 & 1664 & 1743 & 8472 & 1694 \\
\hline & Rata-Rata & 72 & 68 & 71 & 69 & 73 & 353 & 71 \\
\hline
\end{tabular}

Dari data yang telah diperoleh peneliti, ada 15 siswa dari 24 siswa atau 62,5\% mendapat nilai di atas atau sama dengan standar keberhasilan yang telah ditetapkan yaitu $\geq 70$, siswa yang nilainya berada di bawah 70 sebanyak 9 siswa dari 24 siswa atau 37,5\%. Karena ketuntasan kelas kurang dari $80 \%$ maka siklus II harus dilaksanakan.
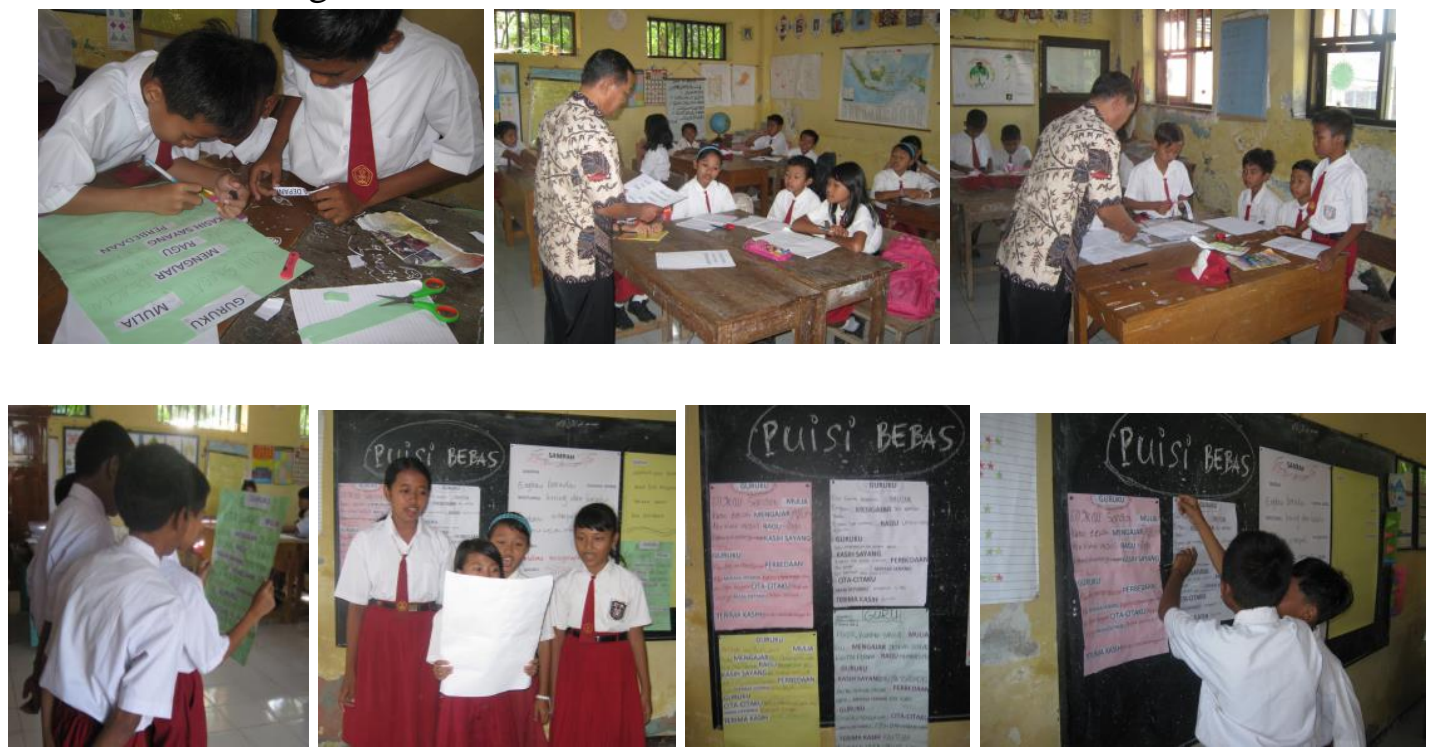

Gambar 2. Praktek penerapan KAKA pada siswa sekolah dasar pada siklus II 
Setelah proses pembelajaran pada siklus II selesai, diakhir siklus diadakan penilaian pembelajaran dengan hasil sebagai berikut :

Tabel 2 : Nilai Prestasi Siswa pada Siklus II

\begin{tabular}{|c|c|c|c|c|c|c|c|c|}
\hline No & Nama Siswa & Diksi & Citraan & \begin{tabular}{|c} 
Kata \\
Konkre
\end{tabular} & $\begin{array}{l}\text { Bahasa } \\
\text { Kiasan }\end{array}$ & Rima & \begin{tabular}{|c|} 
Jumlah \\
Skor
\end{tabular} & $\begin{array}{l}\text { Rata } \\
\text { Nilai }\end{array}$ \\
\hline 1 & Rudi Andriansyah & 78 & 70 & 78 & 74 & 80 & 380 & 76 \\
\hline 2 & Ela Firanti & 78 & 65 & 66 & 70 & 75 & 354 & 71 \\
\hline 3 & Indah Wati & 70 & 65 & 66 & 66 & 70 & 337 & 67 \\
\hline 4 & Moch. Muklis Efendi & 78 & 75 & 72 & 70 & 75 & 370 & 74 \\
\hline 5 & Putri Sukmawati & 82 & 75 & 75 & 74 & 80 & 386 & 77 \\
\hline 6 & Adi Irawan & 86 & 75 & 78 & 80 & 85 & 404 & 81 \\
\hline 7 & Arina Hidayati & 78 & 80 & 72 & 70 & 75 & 375 & 75 \\
\hline 8 & Achmad Zakariya & 82 & 80 & 78 & 76 & 75 & 391 & 78 \\
\hline 9 & Aldina Wahyu W. & 82 & 70 & 72 & 70 & 75 & 369 & 74 \\
\hline 10 & Achmad Alif Asy’ari & 82 & 70 & 72 & 72 & 70 & 366 & 73 \\
\hline 11 & Ari Rusiawan & 70 & 70 & 69 & 66 & 65 & 340 & 68 \\
\hline 12 & Ade Rukmana & 86 & 85 & 84 & 82 & 85 & 422 & 84 \\
\hline 13 & Achmad Saifuddin & 86 & 80 & 81 & 80 & 80 & 407 & 81 \\
\hline 14 & Choirun Nur Asfiah & 82 & 75 & 78 & 76 & 75 & 386 & 77 \\
\hline 15 & Dwi Adinda Sari & 86 & 85 & 84 & 86 & 85 & 426 & 85 \\
\hline 16 & Dinda Nur Sabilah & 82 & 75 & 78 & 78 & 80 & 393 & 79 \\
\hline 17 & Detta Eka Amalia & 82 & 80 & 81 & 76 & 80 & 399 & 80 \\
\hline 18 & Eka Cahyati & 78 & 75 & 75 & 78 & 75 & 381 & 76 \\
\hline 19 & Firdausi Nuzula & 82 & 80 & 81 & 86 & 80 & 409 & 82 \\
\hline 20 & Kamaluddin Zuhri & 78 & 75 & 75 & 76 & 75 & 379 & 76 \\
\hline 21 & M. Zaim Al Faiq & 78 & 75 & 78 & 78 & 80 & 389 & 78 \\
\hline 22 & Muh. Naufal D & 74 & 70 & 75 & 74 & 75 & 368 & 74 \\
\hline 23 & Moh. Efendi Firman & 69 & 65 & 66 & 68 & 70 & 338 & 68 \\
\hline 24 & Moh. Rukhan Hafidz & 78 & 75 & 81 & 80 & 80 & 394 & 79 \\
\hline \multicolumn{2}{|r|}{ Jumlah } & 1907 & 1790 & 1815 & 1806 & 1845 & 9163 & 1833 \\
\hline \multicolumn{2}{|r|}{ Rata-Rata } & 79 & 75 & 76 & 75 & 77 & 382 & 76 \\
\hline
\end{tabular}

Dari data yang telah diperoleh peneliti, ada 21 siswa dari 24 siswa atau 87,5\% mendapat nilai di atas atau sama dengan standar keberhasilan yang telah ditetapkan yaitu 70 , dan 3 siswa dari 24 siswa atau 12,5\% mendapat nilai di bawah 70. Karena lebih dari $80 \%$ siswa mendapat nilai ketuntasan diatas atau sama dengan 70 maka siklus III tidak perlu dilaksanakan.

Untuk memahami secara utuh tentang pengertian keterampilan menulis puisi, berikut ini diuraikan tentang (1) keterampilan, dan (2) menulis puisi. Menurut kamus besar bahasa Indonesia, keterampilan berasal dari kata terampil yang artinya cakap dalam menyelesaikan tugas; mampu dan cekatan. Keterampilan sendiri diartikan sebagai suatu kecakapan untuk menyelesaikan tugas.Keterampilan ialah kegiatan yang berhubungan dengan urat-urat syaraf dan otot-otot (neuromuscular) yang lazimnya tampak dalam kegiatan jasmaniah seperti menulis, mengetik, olahraga dan sebagainya. Meskipun sifatnya motorik, keterampilan itu memerlukan koordinasi gerak yang teliti dan kesadaran yang tinggi. Dengan demikian, siswa 
yang melakukan gerakan motorik dengan kesadaran yang rendah dapat dianggap kurang atau tidak terampil (Muhibbin Syah, 2008:119).

Menurut Reber dalam Muhibbin (2008), keterampilan adalah kemampuan menemukan pola-pola tingkah laku yang kompleks dan tersusun rapi secara mulus dan sesuai dengan keadaan untuk mencapai hasil tertentu. Keterampilan bukan hanya meliputi gerakan motorik melainkan juga pengejewantahan fungsi-fungsi mental yang bersifat kognitif. Konotasinya pun luas sehingga sampai pada mempengaruhi dan mendayagunakan orang lain secara tepat juga dianggap sebagai seorang yang terampil.

Meskipun sampai sekarang orang tidak dapat memberikan definisi secara tepat tentang puisi, namun untuk memahaminya perlu diketahui batasan tentang pengertian puisi. Secara intuitif orang dapat mengerti apakah puisi berdasarkan konvensi wujud puisi, namun sepanjang sejarahnya wujud puisi selalu bermacam-macam.

Taylor melalui Djoko Pradopo (2005:6) mengemukakan puisi itu adalah kata-kata terindah dalam susunan terindah. Penyair memilih kata-kata yang setepatnya dan disusun secara sebaik-baiknya, misalnya seimbang, simetris, antara satu unsur dengan unsur lain sangat erat hubungannya. Hal ini senada dengan Tarigan (1984:7) yang mengutip pendapat Watts, bahwa"Puisi adalah ekspresi yang konkrit dan bersifat artistik dari pikiran manusia dalam bahasa emosional dan berirama". Batasan tentang puisi tiap penyair akan terpengaruh oleh hal-hal yang subyektivitas, hingga akhirnya tidak akan sanggup memberikan sesuatu gambaran tentang puisi itu sendiri secara keseluruhan ( Adhy Asmara, 1982:25). Namun demikian, Adhy Asmara melihat unsur yang terdapat dalam puisi sebagai rujukan mengartikan puisi. Untuk itu, adakah pikiran, perasaan, nada bicara dan maksud dari penyair. Keempat unsur yang ditangkap melalui puisi inilah yang dikenal dengan nama empat arti puisi (Adhy Asmara, 1982 : 29-30 ). Dalam sumber lain disebutkan bahwa puisi adalah bentuk karya sastra yang mengungkapkan pikiran dan perasaan penyair secara imaginatif dan disusun dengan mengkonsentrasikan semua kekuatan bahasa dengan pengkonsentrasian struktur fisik dan struktur batinnya. (Waluyo, 1987:25 )

Jadi, dari definisi-definisi tersebut tampak adanya perbedaan-perbedaan pemikiran mengenai puisi. Namun, seperti dikemukakan Ahmad dalam Pradopo (2005:7) berpendapat bahwa bila unsur-unsur dari pendapat-pendapat itu dipadukan, maka akan didapat garis-garis besar tentang pengertian puisi yang sebenarnya. Unsur-unsur tersebut berupa: emosi, imajinasi, pemikiran, ide, nada, irama, kesan pancaindra, susunan kata, kata-kata kiasan, kepadatan dan perasaan yang bercampur baur.

Rahmanto dalam Sintesis $(2007: 129)$ berpendapat sebagai karya seni, puisi dibangun oleh unsur fisik dan unsur batin. Unsur fisik tampak (kasat mata), sedangkan unsur batin, tidak kasat mata tetapi ada seperti halnya jiwa/roh dan badan dalam tubuh manusia, sebuah puisi yang hanya terdiri dari tubuh saja, maka puisi itu akan "mati"; sebaliknya jika tanpa tubuh maka akan menjadi sulit untuk dilacak. Karya sastra yang berbentuk puisi, sebenarnya mirip seperti bangunan sebuah rumah yang terdiri dari unsur-unsur pembangunnya yang saling berelasi membentuk sebuah struktur yang terdiri dari susunan unsur-unsur yang bersistem. Antara unsur-unsurnya terdapat hubungan timbal balik, dan saling menentukan.

Unsur tubuh dalam puisi adalah unsur yang kasat mata, yang dapat dilihat secara visual; sedangkan unsur jiwa adalah unsur yang tak kasat mata, tetapi dapat kita rasakan. Unsur tubuh (bentuk visualnya) dapat dirinci menjadi : diksi, citraan, kata-kata konkret, majas/lambang/kias/rima dan irama. Unsur jiwa terdiri dari : rasa, nada, amanat/tujuan, dan temanya. Puisi terdiri dari dua unsur yaitu unsur fisik dan unsur batin. Unsur fisik puisi 
meliputi a) diksi, b) citraan, c) kata-kata konkret, d) bahasa kias/majas/symbol, dan e) rima dan irama, sedangkan unsur batin puisi terdiri dari a) rasa, b) nada, c) amanat, dan d) tema.

Untuk menghindari salah penafsiran tentang media KAKA (kartu kata) yang dimaksudkan dalam penilitian ini, peneliti akan menguraikan konsep-konsep yang berkaitan dengan media KAKA yaitu (1) media dan (2) KAKA (kartu kata). Dalam bahasa arab media adalah perantara atau pengantar pesan dari pengirim ke penerima pesan. Gerlch dan Ely dalam Arsyad (2002:3) mengatakan bahwa media apabila dipahami secara garis besar adalah manusia, materi, atau kejadian yang membangun kondisi yang membuat siswa mampu memperoleh pengetahuan, keterampilan, atau sikap. Dalam pengetahuan ini guru, buku teks, dan lingkungan sekolah merupakan media. Secara lebih khusus pengertian media dalam proses belajar mengajar cenderung diartikan sebagai alat-alat grafis, fotografis, atau elektronis untuk menangkap, memproses, dan menyusun kembali informasi visual atau verbal.

Dari uraian tentang beberapa pengertian media, dapat peneliti simpulkan bahwa media dapat diartikan sebagai segala sesuatu yang dapat dimanfaatkan untuk proses komunikasi, penanaman konsep (dari abstrak ke yang konkret) agar siswa memporeleh pengetahuan, ketrampilan, atau sikap. Untuk lebih meningkatkan pemahaman tentang media pembelajaran, peneliti menyajikan pendapat Sudjana dan Rivai dalam Arsyad (1996:24-25) yang mengemukakan manfaat media pembelajaran dalam proses belajar siswa, yaitu: (1) Pembelajaran akan lebih menarik pehatian siswa sehingga dapat menumbuhkan motivasi belajar, (2) Bahan pelajaran akan lebih jelas maknanya sehingga dapat lebih dipahami oleh siswa dan memungkinkannya menguasai tujuan pembelajarannya, (3) Metode mengajar akan lebih bervariasi, tidak semata-mata komunikasi verbal melalui penuturan kata-kata guru, sehingga siswa tidak bosan dan guru tidak kehabisan tenaga, apalagi kalau guru mengajar pada setiap jam pelajaran, dan (4) Siswa dapat lebih banyak melakukan aktivitas belajar sebab tidak hanya mendengarkan uraian guru, tetapi juga aktivitas lain sepeti mengamati, melakukan, mendemonstrasikan, memerankan, dan lain-lain.

KAKA (Kartu Kata) menurut Kamus Besar Bahasa Indonesia, kartu adalah kertas tebal, berbentuk persegi panjang untuk berbagai keperluan, hampir sama dengan karcis (Pusat Bahasa Depdiknas, 2007:510). Kata adalah 1) unsur bahasa yang diucapkan atau dituliskan yang merupakan perwujudan kesatuan perasaan dan pikiran yang dapat digunakan dalam berbahasa. 2) Ujar; bicara: 3) satuan (unsur) bahasa yang terkecil yang dapat diwujudkan sebagai bentuk yang bebas (Pusat Bahasa Depdiknas, 2007:494). Dengan demikian, KAKA (kartu kata) adalah sebuah kartu yang berbentuk persegi panjang yang berisi unsur bahasa yang diucapkan atau dituliskan yang merupakan perwujudan kesatuan perasaan dan pikiran yang dapat digunakan dalam berbahasa.

\section{KESIMPULAN}

Penelitian ini merupakan upaya membantu siswa meningkatkan prestasi belajar siswa SDN Jemirahan kecamatan Jabon Kabupaten Sidoarjo tentang keterampilan menulis puisi melalui media KAKA. Untuk merealisasikan usaha tersebut penelitian dilakukan dengan pretes sebagai tahap penjajakan dan 2 siklus yang terdiri dari 4 komponen yaitu : perencanaan tindakan, pelaksanaan tindakan, observasi, dan refleksi. Setiap pelaksanaan tindakan, peneliti melakukan berbagai langkah sesuai dengan rencana penelitian tindakan kelas. Berikut pembahasan dari setiap pelaksanaan tindakan masing-masing siklus :

Pada penelitian ke-1 (Siklus I), guru melakukan tes awal (pre test) melalui Tanya jawab pada kegiatan awal (apersepsi) sebagai tolak ukur kemampuan individu siswa dan untuk 
mengetahui kesiapan belajar siswa terhadap materi yang akan dipelajari karena siswa sudah pernah menerima pelajaran yang sama pada kelas sebelumnya yaitu kelas IV yaitu tentang menulis puisi, serta melakukan penelitian tindakan kelas dengan menerapkan media KAKA secara klasikal. Setelah diadakan evaluasi berupa tes diperoleh hasil hasil 15 siswa dari 24 siswa atau 62,5\% dapat mencapai nilai ketuntasan yaitu $\geq 70 \%$ dan 9 siswa dari 24 siswa atau 37,5 \% belum dapat mencapai nilai ketuntasan yaitu $\leq 70$ dengan rata-rata 71 .

Pada penelitian ke-2 (siklus II), guru berupaya mengaktifkan siswa dalam proses pembelajaran dengan membimbing siswa melakukan kegiatan diskusi dengan membagi siswa menjadi 8 kelompok. Hal ini dilakukan dengan tujuan agar siswa dapat terlibat secara aktif untuk menemukan sendiri tentang materi menulis puisi. Selain itu siswa juga dituntut untuk bisa menyampaikan pendapatnya pada teman-teman sekelasnya melalui media KAKA di kelas. Setelah diadakan evaluasi melalui tes tertulis diperoleh data yaitu 21 siswa $(87,5 \%)$ dari keseluruhan jumlah 24 siswa sudah mendapatkan hasil belajar diatas nilai ketuntasan dan 3 siswa $(12,5 \%)$ belum mencapai nilai ketuntasan dengan rata-rata 76 sehingga siklus III tidak perlu diadakan. Dengan demikian penggunaan media KAKA dapat meningkatkan prestasi belajar menulis puisis bebas pada kelas V-A SDN Jemirahan kecamatan Jabon Sidoarjo.

\section{DAFTAR PUSTAKA}

Arsyad, Azhar. 2007. Media Pembelajaran. Jakarta: PT Raja Grafindo Persada.

Asmara, Adhi. 1982. Apresiasi Puisi Untuk Pemula. Yogya: Nur Cahaya

Depdiknas. 2005. Bahan Pelatihan Terintegrasi Berbasis Kompetensi Guru SMP Bahasa dan

Sastra Indonesia Pengembangan Kemampuan Menulis Sastra. Dirjen Dikdasmen Direktorat Pendidikan Lanjutan Pertama.

Depdiknas, 2006. Standar Kompetensi dan Kompetensi Dasar.

Depdiknas. 2007. Pengembangan Keterampilan Berbahasa dan Sastra di SD. Bandung: Depdiknas.

Mulyasa, E. 2008. Menjadi Guru Profesional. Bandung: Remaja Rosda Karya.

Purwanto, Ngalim. 2008. Prinsip-Prinsip dan Teknik Pengajaran. Jakarta: Remaja Rosda Karya.

Pusat Bahasa Departemen Pendidikan Nasional. 2007. Kamus Besar Bahasa Indonesia. Jakarta: Balai Pustaka.

Pradopo, Rachmat Djoko. 2005. Pengkajian Puisi. Yogyakarta: Gajah Mada University Press.

Rahmanto, B. 2007. Pembelajaran Apresiasi Puisi di Sekolah Menengah Atas dalam Sintesis.Vol.5 No. 2, Oktober 2007. Pusat Kajian Bahasa: Yogyakarta.

Sudjana, N. dan Rivai. (1990). Media Pengajaran. Dalam Arsyad, Azhar. Media Pembelajaran. (hal.24-25). Jakarta: Rajawali Pers.

Sudjana, Nana. 2008. Penilaian Hasil Proses Belajar Mengajar. Bandung: PT Remaja Rosdakarya.

Syah, Muhibbin. 2008. Psikologi Pendidikan Dengan Pendekatan Baru. Bandung: Remaja Rosda Karya.

Tarigan, H. Guntur. 1984, Prinsip-prinsip Dasar Sastra. Bandung: Angkasa.

Waluyo, Herman J. 1987. Teori dan Apresiasi Puisi. Jakarta : Erlangga 